\title{
Maquetes táteis: infográficos tridimensionais para a orientação espacial de deficientes visuais
}

\section{Tactile scale models: three-dimensional infographics for space orientation of the blind and visually impaired}

\section{LUIS FERNANDO MILAN}

Estudante, Graduando do Curso de Arquitetura e Urbanismo, pela Faculdade de Engenharia Civil, Arquitetura e Urbanismo da Universidade Estadual de Campinas.

Ifernandomilan@gmail.com

\section{Resumo}

A preocupação com a acessibilidade em arquitetura cresce atualmente, ressaltando a necessidade de proporcionar a interação entre o deficiente físico e o espaço construído. $O$ deficiente físico não possui todos os recursos necessários para um reconhecimento eficiente destes espaços, o que the reduz a utilização e vivência no meio comum. Durante este trabalho, foram desenvolvidas maquetes táteis para a Biblioteca Central (BC) da UNICAMP, com a utilização de técnica de fabricação digital. Foi feita, em seguida, a avaliação da eficiência deste método, considerando todos os seus aspectos (dimensões, textura, rigidez, simbologia etc). A análise dos modelos foi feita pelos seus futuros usuários, os deficientes visuais que utilizam o Laboratório de Acessibilidade da BC, situado no interior da biblioteca, como ambiente de trabalho. A técnica de prototipagem rápida utilizada na produção das maquetes foi a Sinterização Seletiva a Laser (SLS), que influenciou, de forma decisiva, diversos fatores táteis dos modelos, como durabilidade, resistência e a possibilidade de produção de elementos pequenos, com grande precisão. As maquetes foram eficientes na orientação dos deficientes visuais no interior do prédio. Conclui-se, contudo, que a eficiência da maquete tátil na orientação de deficientes visuais depende também da capacidade de raciocínio espacial desses usuários, e não apenas da qualidade do modelo.

Palavras-chave: Deficiência visual - Maquete tátil - Prototipagem Rápida

\section{Abstract}

The concern with accessibility in architecture has increased in the past years, as well as the concern to improve the relationship between physically-impaired people and the built environment. Physicallyimpaired, and especially visually-impaired people, do not have all the necessary resources for an 


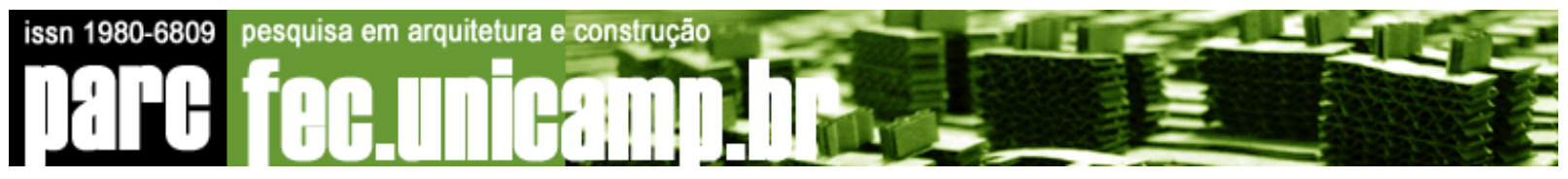

efficient recognition of the space, which reduces their ability to use it. In this research tactile models for UNICAMP's Central Library $(B C)$ were developed using a digital fabrication technique. Next, the efficiency of this method was evaluated, taking into account all its aspects (dimensions, texture, rigidity, simbology used, etc.). The evaluation of the models was done by their future users, the visually impaired and blind people that work at BC's Accessibility Lab, inside the library. The rapid prototyping technique used for producing the models was the selective laser syntherization (SLS), which influenced different aspects of the models, such as their durability, resistence, and the possibility of producing small details with high precision. The models proved very helpful in orienting the visually-impaired and blind people inside the building. It was possible to conclude, however, that the orientation of these subjects depends also on their personal ability for spatial thinking, and not only on the quality of the models.

Keywords: Visual impaired - Tactile scale models - Rapid Prototyping

\section{MAQUETES TÁTEIS: INFOGRÁFICOS TRIDIMENSIONAIS PARA A ORIENTAÇÃO ESPACIAL DE DEFICIENTES VISUAIS.}

O objetivo deste artigo é responder a uma pergunta que envolve dois pontos significativos, envolvendo duas áreas de estudo (o desenho universal e a computação gráfica): é possível desenvolver uma maquete tátil com a utilização da prototipagem rápida? Para respondê-la, foi necessário estudar, por um lado, a percepção espacial por parte dos deficientes visuais, incluindo técnicas de produção de maquetes táteis a partir de materiais mais tradicionais, e, por outro, técnicas de computação gráfica e prototipagem rápida.

\section{Introdução}

Como auxílio no desenvolvimento psicológico de um deficiente visual, é de grande importância a formação da noção espacial do ambiente no qual ele circula, para que sua locomoção e socialização possam ser melhoradas.

Existem alguns métodos de reconhecimento espacial comumente utilizados por cegos, como, por exemplo, a experiência direta com o ambiente, na qual as informações essenciais para a movimentação dentro dele são obtidas e memorizadas a partir do contato com cada objeto e obstáculo. Embora eficiente, este método é demorado e nem sempre possível, sobretudo quando se trata de um ambiente muito amplo. Além disso, o conhecimento do espaço em geral se restringe apenas ao traçado de rotas e detecção de obstáculos. 


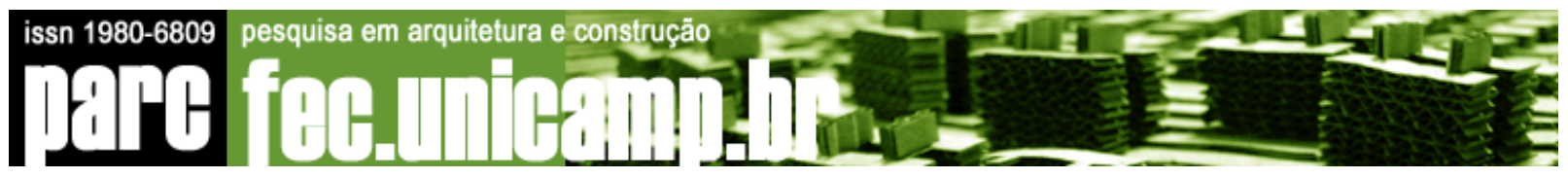

No entanto, alguns artifícios podem ser utilizados para auxiliar na memorização de um espaço ou mesmo na percepção de alguns fatores. A utilização de mapas táteis é um desses recursos, que apesar de não substituírem as sensações da experiência direta são muito eficientes na transmissão de informações mais precisas.

Segundo UNGAR, S., BLADES, M. \& SPENCER, C. (1995), mapas táteis são eficientes, em especial, para adultos com visão subnormal:

Mapas táteis podem ser importantes recursos de informação para pessoas com visão subnormal, proporcionando uma visão geral do ambiente e de todas as relações espaciais entre os lugares dentro dele. Tal informação pode ser obtida a partir de um mapa muito mais rapidamente que através da exploração direta de um espaço, e muitos estudos têm mostrado que mapas e modelos táteis podem ajudar adultos a ganhar um entendimento efetivo de um ambiente.

(UNGAR, S., BLADES, M. \& SPENCER, C., 1995, pág. 27) (tradução do autor).

É importante ressaltar que a formação de uma imagem mental é ideal para a percepção total do espaço, uma vez que permite ao deficiente visual ordenar e relacionar os elementos contidos neste espaço mais fácil e dinamicamente e, portanto, se locomover com maior independência e segurança.

UNGAR, S., ESPINOSA, A., BLADES, M., OCHAÍTA, E. \& SPENCER, C.(1996) enfatizam a importância dos mapas táteis na formação da imagem mental de um ambiente:

Mapas táteis têm grande potencial a este respeito. Foi mostrado em alguns estudos que cegos e pessoas com deficiência visual têm dificuldade em construir uma representação precisa e flexível de ambiente através da locomoção direta, por ele mesmo. Mapas, que disponibilizam a estrutura espacial do ambiente em uma escala acessível ao toque e sem os efeitos de desorientação associados ao "deslocamento" no mundo real, podem superar esta dificuldade. (1996, pág.1) (tradução do autor)

Em resumo, a importância da utilização de mapas táteis por portadores de deficiência visual é indiscutível, assim como o uso de outros tipos de estímulos, sejam táteis, olfativos ou auditivos, uma vez que auxiliam na substituição do canal sensorial de maior importância na aquisição de informações sobre o espaço. Em razão disso, diversas pesquisas têm sido realizadas na tentativa de estabelecer as melhores formas de representação dos elementos de um ambiente, além dos materiais mais adequados para a produção de mapas táteis. Outras, ainda, focalizam os aspectos psicológicos de um mapa tátil, estudando as melhores combinações de transmissão de informações ou o modo como as representações mentais são feitas. 
No entanto, é comum que nessas experiências sejam avaliados itens isolados, o que não permite o estabelecimento de um conjunto total de fatores, um método correto, ideal, de se produzir um mapa tátil. Apesar disso, muitas conclusões podem ser tiradas a respeito de cada item, facilitando a escolha de materiais e métodos para a produção de uma maquete.

Este estudo tem a intenção de realizar experiências que englobam diferentes aspectos de uma maquete tátil, através de um estudo de caso. São avaliados itens que compreendem desde a eficiência da escolha dos símbolos para a transmissão de informações até a adequação do material escolhido, uma vez que é proposta a utilização de material e método específicos, o que permite a verificação de seu efeito em comparação a outros materiais.

\section{Maquetes táteis}

As maquetes táteis são recursos de captação de informações que auxiliam o deficiente visual na compreensão do espaço ao seu redor, contribuindo para sua independência na locomoção, com maior eficácia se utilizado em conjunto com outras formas de reconhecimento do espaço.

A sua produção, portanto, deve ser cuidadosa na representação dos fatores principais de cada ambiente, uma vez que existe uma imensa diferença entre o que o vidente enxerga e o que o deficiente visual sente, percebe. Da mesma forma, os símbolos devem ser precisos no fornecimento de informações, a fim de não confundir e atrapalhar na formação de imagens das rotas e das características dos ambientes. Segundo UNGAR, BLADES E SPENCER (1995), “(...) o leitor com deficiência visual deve descobrir estas informações construindo-as através do reconhecimento seqüencial do mapa, formando estruturas de referências e gradualmente estabelecendo uma impressão geral e integrada do mapa”. (Ungar, S., BLADES, M. \& SPENCER, C. ,1995, pág.27) (tradução do autor)

Durante a pesquisa pode-se perceber que existem diferentes tipos de maquetes táteis. Existem, por exemplo, diferenças entre mapas táteis e maquetes táteis. Apesar dos métodos serem bem parecidos, o mapa tátil procura reproduzir caminhos e fluxos, sem tomar como ponto principal a representação do espaço como as dimensões dos ambientes, tentando fornecer informações sobre as rotas a serem percorridas de maneira mais simplificada, com a intenção de possibilitar ao deficiente visual maior independência no seu deslocamento.

Já a maquete tátil possui representados os elementos que delimitam os espaços, caracterizando-se pela forma, proporção e relação mais realista com o entorno. As paredes, 
portas e a legenda são os fatores que guiam o indivíduo pelo edifício. HOLMES ET AL. (1998) esclarecem as diferentes funções desses dois tipos de representação:

(...) preferiram o mapa de paredes ${ }^{*}$, citando melhor imagem; por exemplo, o sangramento para uma porta parece mais lógico como símbolo do que um ponto usado no mapa de piso*. (...) preferiram a simplicidade do mapa de piso, alegando não necessitarem saber a forma de uma sala a menos que eles estejam trabalhando no edifício e que era mais fácil localizar coisas seguindo linhas pontilhadas.

(HOLMES, E., ET. AL 1998, p.532). (tradução do autor)

Para esta pesquisa, foram utilizadas as duas técnicas. A primeira maquete, que tem o objetivo de conduzir o deficiente visual através do hall de entrada e escadas da Biblioteca Central da UNICAMP até o Laboratório de Acessibilidade, inclui elementos das duas técnicas, pois apesar de incluir as paredes e os espaços como um todo, possui também a demarcação do caminho a ser percorrido. Procurou-se representar todos os espaços, fazendo com que a rota pudesse ser descoberta segundo a localização desses elementos ao longo do edifício, além da demarcação do caminho no piso da maquete. A segunda maquete, que tem como objetivo explicar o espaço no interior do Laboratório de Acessibilidade, pode ser descrita como uma maquete tátil, também chamada de mapa de paredes ou wall map (HOLMES ET AL., 1998), onde não há demarcação de rotas no interior do espaço.

Quanto aos materiais utilizados, podem variar conforme a necessidade de representação. São encontradas pesquisas que avaliam alguns materiais, que se baseiam nas texturas e no detalhamento que cada um deles possibilita. Porém, é de difícil discussão a eficiência de cada um, uma vez que este fator depende de outras variáveis, como os detalhes necessários, a durabilidade requerida, as experiências individuais dos deficientes visuais usuários da maquete, entre outros. Em pesquisa voltada para os materiais de confecção das maquetes táteis, realizada por Jehoel, S., et. al. (2005), fica claro o aspecto relativo dos materiais. Os resultados mais favoráveis são em relação às superfícies equilibradas, que não são nem tão ásperas nem tão lisas, porém há constatações de preferências por materiais de todos os tipos.

$\mathrm{Na}$ disciplina eletiva de Desenho Universal, cursada na FEC no $2^{\circ}$ semestre de 2005, foram apresentadas maquetes com diferentes materiais, como EVA, papel chumbo, tecido, barbantes, serragem, papel sulfite, isopor, entre outros comuns na produção de maquetes. $\mathrm{Na}$ avaliação da eficiência destas maquetes, o fator aspereza não foi decisivo (não estava acima, por exemplo, da importância do formato da maquete), a não ser que atrapalhasse no reconhecimento de algum símbolo, por exemplo. 


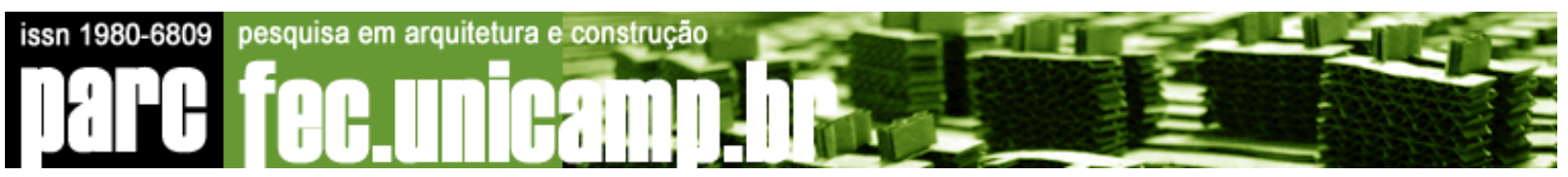

O problema, no entanto, no uso desses materiais, é que as maquetes não possuem grande durabilidade, já que são expostas a constante manuseio. Além disso, o grau de detalhes é reduzido, uma vez que é difícil reproduzir pequenos elementos com a perfeição requerida pelo tato, e que ao mesmo tempo tenham durabilidade. O Braille, por exemplo, para que siga as dimensões estabelecidas pela norma, deve ser feito em papel, o que resiste apenas a poucos toques (não é adequado para uma maquete, em que existe necessidade de reconhecimento e um maior esforço é inevitável).

Dessa forma, um dos aspectos que foram avaliados nesta pesquisa foi justamente a adequação do material utilizado na confecção das maquetes táteis produzidas: a resina sinterizada a laser, por técnica de prototipagem rápida. Esta adequação foi quantificada tendo em vista os critérios de clareza dos símbolos em Braile e o conforto tátil descrito pelos deficientes que as experimentaram.

\section{Prototipagem rápida}

A prototipagem rápida, também conhecida como impressão 3D, é a construção automática de objetos físicos a partir de modelos digitais. A primeira técnica de prototipagem rápida se tornou possível nos anos 80, e foi utilizada na produção de modelos e partes de protótipos. Hoje em dia, estas técnicas são usadas para uma grande gama de aplicações, inclusive na produção de objetos para uso final em pequenas quantidades. Alguns escultores empregam esta tecnologia para produzir formas complexas, para exposições de arte.

Existem diferentes maneiras de se produzir modelos por prototipagem rápida. Uma técnica comum de prototipagem rápida consiste em tomar um modelo tridimensional virtual modelado em software de CAD (computer-aided design), transformá-lo em finas seções, ainda virtualmente, e então converter cada seção em uma camada de material, uma sobre a outra, até que o modelo esteja terminado. Neste tipo de fabricação, conhecida como aditiva, a máquina adiciona sucessivas camadas de material líquido (como plástico fundido) ou em pó (como gesso, seguido de uma cama de aglutinante), e dessa maneira, constrói o modelo. Em outra técnicas semelhante, as camadas do modelo em CAD são coladas ou fundidas, geralmente por meio de laser, automaticamente, criando a forma final. A principal vantagem da construção aditiva é a possibilidade de criar quase todo tipo de geometria, exceto volumes internos fechados. Outras técnicas de prototipagem rápida são apresentadas na Tabela 1, com exemplos de aplicações. 


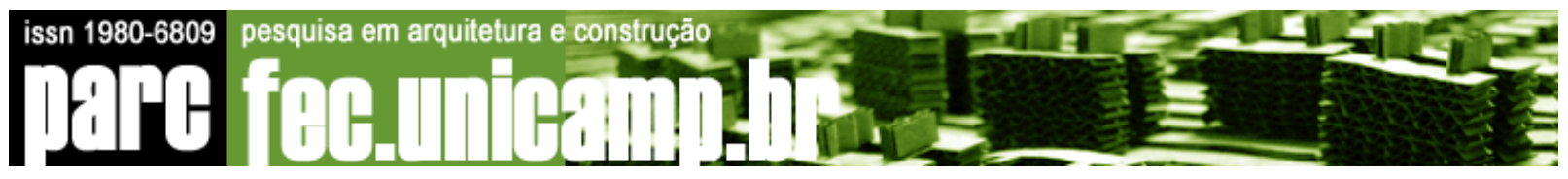

A interface padrão entre software CAD e a máquina de prototipagem rápida é o formato de arquivo STL, ou seja, é a partir de arquivos com essa extensão a máquina consegue ler o modelo virtual e reproduzi-lo.

A palavra "rápida" é relativa: a construção de um modelo com as máquinas atualmente disponíveis pode levar diversos dias, dependendo do tipo de máquina e do tamanho do modelo. Usada em micro tecnologia, este termo está correto: os produtos são feitos rapidamente e as máquinas podem construir as partes em paralelo.

Avanços na tecnologia permitem que a máquina use múltiplos materiais na construção dos objetos. Isto é importante porque se pode usar um material com alto ponto de fusão para o produto final, e outro material com um baixo ponto e fusão como "preenchimento", o que separa partes móveis individuais do restante do modelo. Depois de concluído, o modelo é aquecido até o ponto em que o material de preenchimento se derrete, e o que resta é uma peça funcional.

O elevado custo da produção de modelos por prototipagem rápida ainda é um dos fatores que impedem sua utilização mais extensiva. A moldagem tradicional de injeção é ainda muito mais barata para manufaturar produtos para uso final em larga escala. Assim, o uso da prototipagem rápida só se justifica na produção de modelos e protótipos destinados a ensaios, ou a peças que serão produzidas apenas uma vez, como é o caso, em geral, das maquetes arquitetônicas e táteis. Contudo, pesquisas vêm sendo feitas com o objetivo de reduzir os custos da produção de objetos por máquinas de prototipagem, o que poderá vir a viabilizar seu uso para novas aplicações.

Para a produção das maquetes desta pesquisa, foi feita, primeiramente, a modelagem em software AutoCAD, considerando alguns cuidados necessários para que o modelo possa ser lido sem problemas pela máquina, como por exemplo, unir todos os sólidos, dimensionar as espessuras de acordo com a resolução da máquina (como as paredes que tiveram que ser engrossadas proporcionalmente à escala da maquete) e fazer com que a base fosse oca, para evitar desperdício de material. 


\begin{tabular}{|c|c|c|c|c|c|}
\hline Técnica & $\begin{array}{l}\text { Tipo de } \\
\text { modelo } \\
\text { digital }\end{array}$ & $\begin{array}{c}\text { Materiais que podem ser } \\
\text { utilizados }\end{array}$ & $\begin{array}{l}\text { Descrição da } \\
\text { técnica }\end{array}$ & $\begin{array}{l}\text { Exemplos de } \\
\text { maquetes que } \\
\text { podem ser } \\
\text { produzidas }\end{array}$ & Restrições \\
\hline $\begin{array}{l}\text { Corte a laser } \\
\text { Ex: Universal } \\
\text { Laser Systems }\end{array}$ & $2 \mathrm{D}$ & $\begin{array}{l}\text { Placas de Acrílico, } \\
\text { papelão, madeira. }\end{array}$ & $\begin{array}{l}\text { São cortadas } \\
\text { diversas camadas } \\
\text { que em seguida são } \\
\text { sobrepostas e } \\
\text { coladas. }\end{array}$ & Curvas de nível & $\begin{array}{l}\text { Impossível } \\
\text { escrever em } \\
\text { braile ou obter } \\
\text { detalhes em } \\
\text { alto relevo. } \\
\end{array}$ \\
\hline Fresa & 3D & $\begin{array}{l}\text { Blocos de madeira, MDF e } \\
\text { outros materiais sintéticos. }\end{array}$ & $\begin{array}{l}\text { O material é } \\
\text { "esculpido" por um } \\
\text { braço mecânico. }\end{array}$ & $\begin{array}{l}\text { Topografia, baixo } \\
\text { relevo. }\end{array}$ & $\begin{array}{l}\text { Impossível } \\
\text { escrever em } \\
\text { braile e ter } \\
\text { sulcos com } \\
\text { ângulo } \\
\text { negativo. }\end{array}$ \\
\hline $\begin{array}{l}\text { Deposição de } \\
\text { material } \\
\text { Ex. FDM (Fusion } \\
\text { Deposition } \\
\text { Modeler) e Zcorp }\end{array}$ & $3 \mathrm{D}$ & $\begin{array}{l}\text { Resina + pó de gesso ou } \\
\text { amido, plásticos derretidos. }\end{array}$ & $\begin{array}{l}\text { A máquina deposita } \\
\text { gotículas de resina } \\
\text { em camada por } \\
\text { camada de pó. }\end{array}$ & $\begin{array}{l}\text { Qualquer tipo de } \\
\text { maquete, inclusive } \\
\text { com inscrições em } \\
\text { braile, dependendo } \\
\text { da resolução da } \\
\text { máquina. }\end{array}$ & $\begin{array}{l}\text { Resolução } \\
\text { impede alguns } \\
\text { detalhes. }\end{array}$ \\
\hline $\begin{array}{c}\text { Solidificação de } \\
\text { material } \\
\text { Ex: SLS, Polyjet }\end{array}$ & 3D & $\begin{array}{l}\text { Resina especial líquida ou } \\
\text { em pó que se solidifica na } \\
\text { presença de algum tipo de } \\
\text { luz ou raios laser. }\end{array}$ & $\begin{array}{l}\text { Um raio laser ou } \\
\text { outro tipo de luz é } \\
\text { aplicado em } \\
\text { varreduras } \\
\text { sucessivas sobre } \\
\text { um recipiente com a } \\
\text { resina, que vai se } \\
\text { solidificando } \\
\text { camada por camada } \\
\text { até formar o modelo. }\end{array}$ & $\begin{array}{l}\text { Todas, com alto } \\
\text { grau de definição e } \\
\text { durabilidade. }\end{array}$ & $\begin{array}{l}\text { Custo muito } \\
\text { elevado. }\end{array}$ \\
\hline
\end{tabular}

Tabela 1: Principais técnicas de prototipagem rápida.

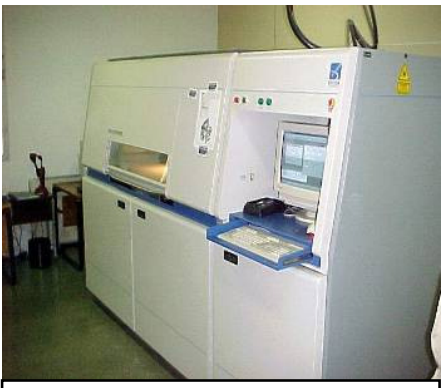

Fig. 1: Máquina utilizada na produção das maquetes (SLS)

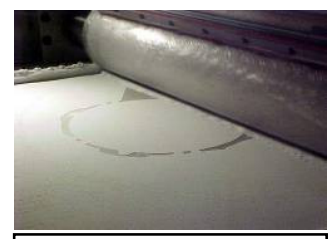

Fig. 2: Detalhe da produção de uma peça em SLS

Depois disso, o modelo foi exportado em arquivo STL, como citado anteriormente, e modificado em no programa SolidWorks, para que a escala do objeto fosse ajustada ao volume de produção (build) máquina. Um dos modelos teve de ser subdividido em quatro partes, para que o tempo de execução total fosse diminuído. 
Finalmente, os modelos foram produzidos pela máquina Sinterstation 2000 (fabricante: 3D Systems), que utiliza a técnica de sinterização seletiva a laser (SLS), utilizando como material construtivo a poliamida (Nylon) em pó (Figs. 1 e 2).

\section{Descrição do Experimento}

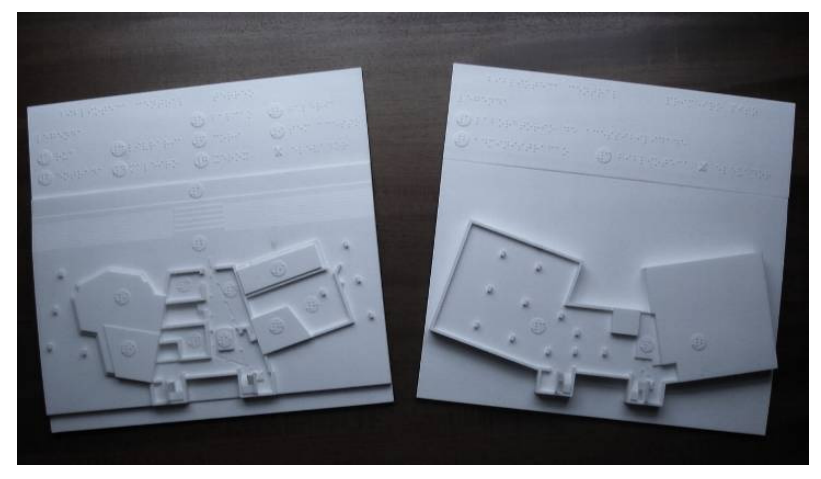

Fig. 3: Maquete tátil 1, em duas partes - à esquerda, térreo da biblioteca central e à direita, primeiro piso, com suas respectivas legendas.

Para a realização do experimento, foram produzidas duas maquetes táteis em Prototipagem Rápida. A primeira delas (Fig. 3) é composta por duas partes, que representam os dois pavimentos da Biblioteca Central, pelos quais os deficientes visuais circulam até chegar ao laboratório de acessibilidade, no $1^{\circ}$ pavimento. Ela compreende o térreo (entrada principal) e o primeiro piso. Seu objetivo é fornecer informações gerais sobre todos os ambientes da biblioteca e as relações espaciais entre eles, criando a visualização de um percurso, desde a escadaria principal (exterior) até o laboratório de acessibilidade, utilizando-se de uma escala maior, que pudesse abranger todo o perímetro do edifício e ao mesmo tempo fornecesse uma quantidade adequada de informações para que os espaços fossem reconhecidos através do tato.

A segunda maquete (Fig. 4) representa o laboratório de acessibilidade, compreendendo o percurso de chegada pela escada (como forma de localizá-lo na biblioteca) até o detalhamento dos móveis mais importantes para o deslocamento do deficiente visual no interior do local. Seu objetivo é proporcionar maior reconhecimento das formas principais da sala, revelando todos os seus objetos principais. Para isso, foi utilizada uma escala menor, o que permitiu adicionar mais detalhes, cumprindo com o objetivo principal da maquete. 

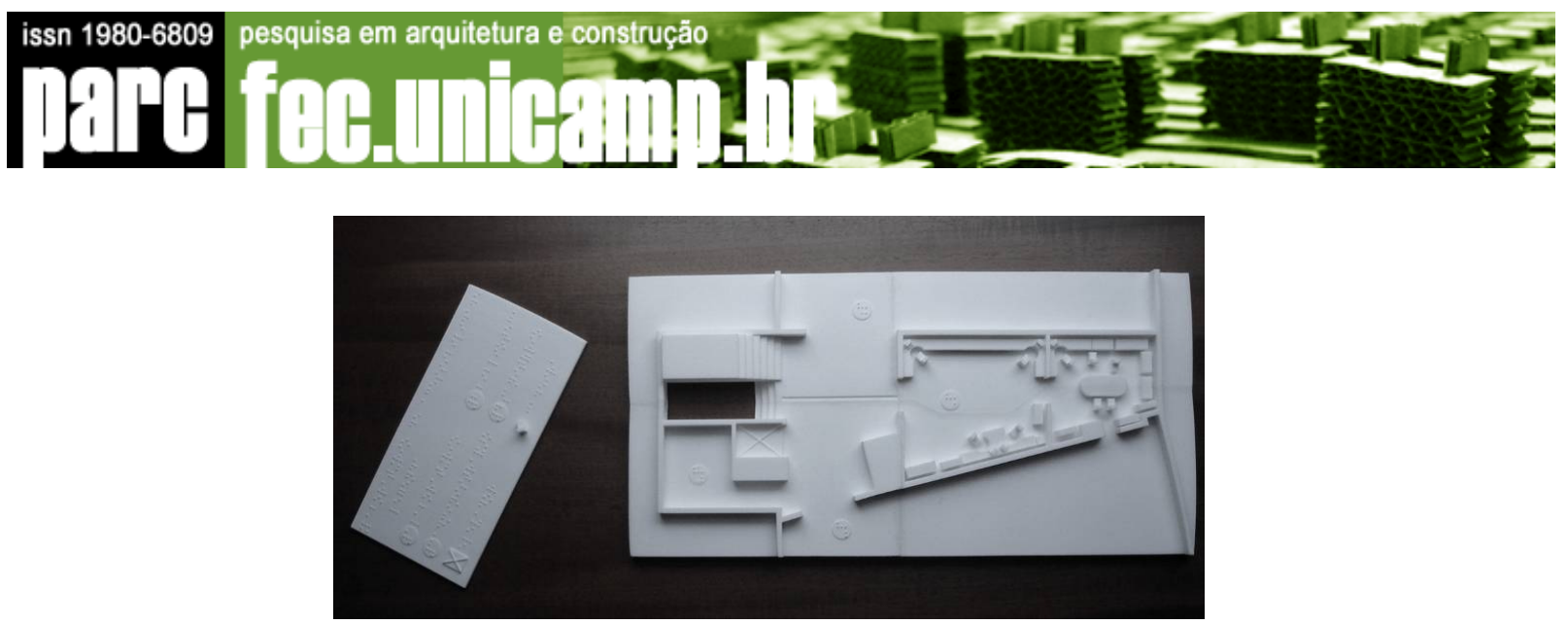

Fig. 4: Maquete tátil 2 - laboratório de acessibilidade e legenda.

\section{A produção das maquetes}

A construção das maquetes teve início com a obtenção das plantas da biblioteca em arquivos digitais para AutoCAD na Coordenadoria de Projetos da Faculdade de Engenharia Civil, Arquitetura e Urbanismo da UNICAMP (CEPROJ). Em seguida, foi realizado um levantamento fotográfico da biblioteca, a fim de facilitar a percepção de detalhes que possuem maior ou menor importância na representação. Foram realizadas, também, medições no local, uma vez que o laboratório é recente, sem documentação precisa.

A partir destes dados, foram feitas adaptações para que se pudesse modelar cada elemento com dimensões adequadas à sua representação em escala. Por exemplo, a espessura das paredes teve de ser aumentada, pois do contrário elas ficariam muito finas e, portanto muito suscetíveis a serem quebradas durante o manuseio das maquetes. $O$ formato e altura do balcão também foram adaptados para permitir a passagem de um dedo ao seu redor, na maquete em escala. Modelos virtuais de diferentes alternativas de maquetes táteis foram desenvolvidos em AutoCAD. Nesse processo também foram inseridos os códigos Braille, através da modelagem destes componentes em 3D, segundo as dimensões estabelecidas pela norma (ABNT - NBr9050). Em seguida, foi feita uma avaliação visual desses modelos na tela do computador, seguida por ajustes e simplificações, até que se chegasse a um modelo aparentemente eficiente.

Os modelos selecionados do primeiro e segundo pavimentos foram usados para a produção em Prototipagem Rápida. O processo de criação destes modelos está demonstrado no anexo A.

As maquetes produzidas possuem as seguintes dimensões: 


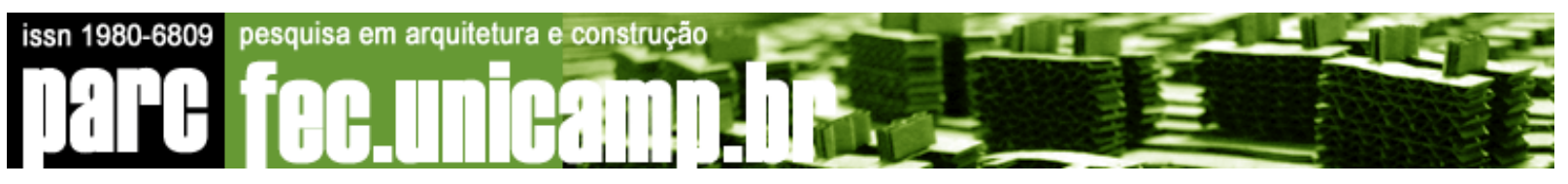

- As duas maquetes da biblioteca central possuem dimensões equivalentes, com $30 \mathrm{~cm}$ de comprimento por $22 \mathrm{~cm}$ de largura cada. As legendas possuem $10 \mathrm{~cm}$ por $30 \mathrm{~cm}$.

- A maquete do laboratório de acessibilidade possui $40 \mathrm{~cm}$ por $20 \mathrm{~cm}$ e sua legenda, $10 \mathrm{~cm}$ por $20 \mathrm{~cm}$.

O processo de produção total durou cerca de 144 horas, tendo sido dividido em duas etapas (72 horas cada), já que as duas primeiras maquetes, em escala aproximada de 1:300, foram feitas juntas e mais tarde é que foi produzida a maquete do laboratório, em escala cinco vezes maior que a primeira maquete.

Como citado na tabela acima, a desvantagem da técnica de SLS é o custo. Os três modelos custaram, ao todo, aproximadamente $\mathrm{R} \$ 13.000,00$. No entanto, a qualidade do material, como a imensa durabilidade e resistência ao tato são fatores atenuantes.

\section{A avaliação das maquetes}

Após sua produção, a primeira maquete foi apresentada a alguns deficientes visuais usuários do laboratório de acessibilidade, para que fosse testada e avaliada segundo sua eficiência (como formação de imagem mental, reconhecimento espacial, transmissão de informações etc.).

O material, as formas, os símbolos, as disposições de legenda, as seqüências da maquete e suas posições uma em relação à outra são os aspectos que foram analisados pelos indivíduos, fornecendo base para se perceber possíveis erros na elaboração da maquete, além dos conceitos ou elementos que mais chamam a atenção destas pessoas e que mereciam ser representados no modelo.

Com base em algumas conclusões das entrevistas da primeira maquete (da biblioteca central), foi desenvolvida a segunda maquete (do laboratório de acessibilidade), do mesmo modo como a primeira, utilizando-se plantas, medições, mas principalmente fotos. Fizeramse, então, adaptações que melhorassem a leitura pelos entrevistados. Mesmo assim, durante sua avaliação, surgiram novos problemas relativos aos diferentes objetivos e maior escala dessa maquete.

As entrevistas com os futuros usuários das maquetes táteis foram realizadas no próprio Laboratório de Acessibilidade, na Biblioteca Central da UNICAMP. Os participantes eram 
freqüentadores do laboratório, com características variadas de idade, sexo, nível de instrução, etc. Ao todo, foram entrevistados seis indivíduos, descritos a seguir:

$\checkmark$ Segundo o sexo, os participantes são quatro homens e duas mulheres. Analisando os resultados, este fator não pode ser considerado como decisivo na avaliação da maquete, ou seja, as percepções de ambos os sexos são parecidas. Por esta razão, não é válido analisar os dados abaixo tomando este aspecto em consideração (é apenas um grupo de 6 pessoas).

$\checkmark$ A idade é outro fator importante dos indivíduos, estando compreendida entre 24 e 50 anos (as mulheres estão presentes nos extremos e os homens são divididos neste intervalo). Mas assim como o sexo, a idade não influenciou nas respostas de forma clara. Pode-se apenas perceber que existe maior aceitação do método pelos indivíduos mais novos.

$\checkmark$ A escolaridade também varia dentre 0 seis entrevistados, mas não suficientemente. Um está concluindo o ensino médio, outro está concluindo o ensino superior e quatro possuem superior completo, além de pós-graduação (em vários níveis). Quanto a este aspecto, não foi possível perceber grandes divergências, uma vez que o intervalo não está muito bem definido, com classificações que possuem apenas um representante.

Segundo os critérios de classificação acima, todos os indivíduos tiveram desempenho semelhante, ou seja, todos os aspectos da maquete foram percebidos e conseguiram ser avaliados, inclusive o Braille. Contudo, o número de indivíduos entrevistados não foi grande o suficiente para que esta pesquisa tenha uma representatividade estatística. Pelo contrário, procurou-se valorizar os aspectos qualitativos, e não quantitativos dos resultados.

$\checkmark$ O tipo de deficiência visual, ao contrário do que aconteceu anteriormente, é um fator decisivo na avaliação das maquetes táteis, se analisado em conjunto com a freqüência de uso dos ambientes da Biblioteca Central. Em números, três indivíduos possuem cegueira total adquirida em idades já avançadas, um possui cegueira total adquirida em idade reduzida, um possui cegueira total congênita e um possui baixa visão.

Como foi dito, este fator possui importância essencial nas avaliações e impressões das maquetes. Isso se dá por causa do tipo de relação que cada indivíduo tem ou teve com os espaços arquitetônicos, físicos e com a própria biblioteca. Em razão da variedade de respostas, são descritas algumas características das entrevistas abaixo, a fim de deixar clara a influência do tipo de deficiência visual na leitura das maquetes: 
Um dos entrevistados (com cegueira total adquirida) já conhecia a Biblioteca Central visualmente, o que facilitou no reconhecimento da maioria espaços, ou, como dito por ele, a maquete ajudou a "resgatar" a imagem mental que já possuía da biblioteca (durante a entrevista, o indivíduo fazia descrições de elementos que não estavam indicadas na maquete, mas que ele sabia que existiam, apenas confirmando suas memórias).

Entretanto, o participante que possui cegueira total adquirida em idade reduzida apresentou bastante conhecimento sobre vários pontos da biblioteca, o que não permite concluir que houve maior ou menor facilidade de leitura entre este e o participante anterior. Segundo o próprio, ele teve este bom desempenho nas percepções das maquetes por causa do seu senso de direção e da facilidade com que constrói "mapas mentais" dos locais que freqüenta. Neste caso, a maquete auxiliou na confirmação dos trajetos que utiliza para acessar o laboratório e na percepção do modo como são distribuídos os ambientes.

Os outros dois participantes, que possuem cegueira total adquirida em idade avançada, tiveram resultados bem parecidos. A maquete, nestes casos, funcionou como primeiro contato com os aspectos formais do edifício. Segundo eles, a maquete facilitou a percepção de elementos como a escada e seu funcionamento, uma vez que já existia conhecimento visual prévio deste tipo de elemento arquitetônico.

O indivíduo com cegueira total congênita apresentou dificuldades na interpretação de alguns elementos da maquete, como a escada. Para ele, o funcionamento e disposição da circulação vertical são confusos, uma vez que não se consegue fazer o reconhecimento tátil no local de maneira adequada. Apesar disso, a escada foi decifrada e a leitura foi bemsucedida.

A entrevista mais peculiar foi com o indivíduo de visão subnormal, que além de se utilizar do tato, consegue enxergar alguns aspectos da maquete. O que acontece é que o sentido da visão, apesar de prejudicado é o mais utilizado, aproveitando-se dos efeitos de luz e sombra (provocados pela altura dos elementos) e da facilidade de manuseio da maquete que é disposta mais perto dos olhos. O tato, neste caso é utilizado, basicamente como solução para as dúvidas que a baixa visão pode provocar, já que não se podem identificar todos os detalhes.

$\checkmark$ Quanto à freqüência de uso do laboratório por parte dos entrevistados, pode-se dizer que ela determinou algumas facilidades na percepção de vários fatores da maquete. Os entrevistados que mais freqüentam o laboratório conseguem, por exemplo, descrever e identificar na maquete o trajeto principal com maior facilidade. Apesar disso, a maquete 


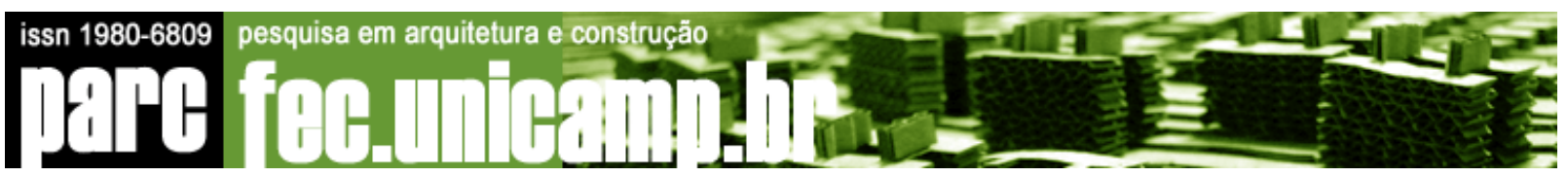

conseguiu retratar bem os ambientes, já que não houve grandes complicações para que os indivíduos que nunca haviam estado na biblioteca ou que raramente a visitam conseguissem decifrar ou descrever os caminhos.

$\checkmark$ O uso e conhecimento do Braille é outro exemplo de fator que não pode ser avaliado durante as entrevistas, considerando que todos os entrevistados tinham contato com os símbolos e usava-os frequentemente, nas suas atividades diárias. Entretanto, não é difícil perceber que se não existisse o conhecimento do Braille, seria extremamente complicado fazer a leitura da maquete, já que não seria possível adquirir informações pelas legendas, que indicam os principais pontos do modelo.

$\checkmark$ Quanto a ter contato com maquetes táteis anteriormente, a maior parte dos participantes já haviam tido esta experiência, mas com certas diferenças. Foram citados mapas táteis, que indicam apenas trajetos, maquetes táteis de relevos, usados no aprendizado de geografia, e apenas uma maquete tátil com os mesmos objetivos daquelas apresentadas, porém com diferenças físicas importantes, como descreveu o próprio participante. A maquete previamente utilizada era de maiores dimensões, possuía mais informações e podia ser tateada por várias pessoas ao mesmo tempo.

Portanto, este fator não influenciou nas respostas de modo significativo, uma vez que todos tiveram contato com algum tipo de maquete, mas com objetivos e importâncias diferenciadas.

$\checkmark$ Já sobre o conhecimento do restante dos espaços da biblioteca, pode-se dizer que os participantes que conheciam mais e melhor os ambientes da biblioteca não tiveram surpresas ao fazer o reconhecimento da maquete, utilizando esta condição orientação, confirmando o que já era sabido. Os outros passaram a entender melhor as disposições dos ambientes, além de suas dimensões.

As entrevistas foram compostas pelas seguintes etapas:

\section{Apresentação dos objetivos:}

No começo de cada entrevista, foi feita uma breve apresentação, com a intenção de apontar os objetivos principais da pesquisa e explicar as formas de obtenção de informação. 0 objetivo principal se resume à avaliação das maquetes, tomando em consideração todos os seus aspectos, como formas, dimensões, símbolos, materiais, etc. Desta forma, era feita uma 


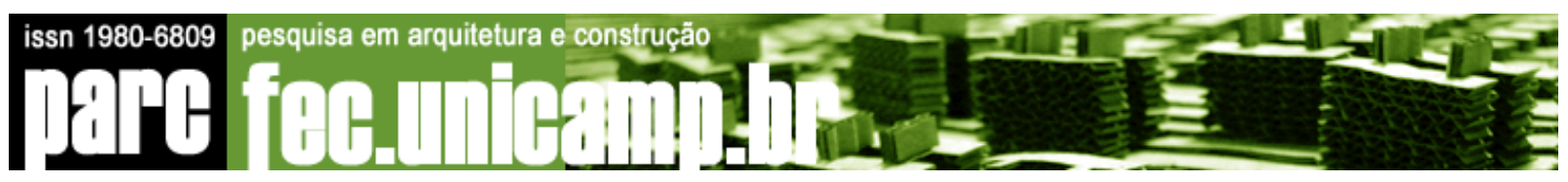

pequena apresentação das maquetes que o participante iria tatear e descrever, para que houvesse menor receio no momento da avaliação.

Quanto à obtenção de informações, explicou-se que a intenção era que o entrevistado se sentisse a vontade para fazer comentários sobre a maquete a qualquer momento, fossem esses negativos ou positivos, indicando ou não possíveis soluções para os problemas encontrados.

Assim, foram realizadas entrevistas semi-estruturadas, ou seja, sem que houvesse um roteiro rígido, com perguntas pré formuladas, mas apenas foi seguida uma ordem lógica, que se estabelecia de maneira mais flexível, respeitando as impressões que cada indivíduo teve sobre as maquetes e explorando melhor suas sensações.

\section{Explicação sobre as técnicas utilizadas:}

Ainda fazendo parte da apresentação, a forma de produção e os materiais utilizados foram descritos, com a finalidade de deixar claro outro objetivo da avaliação, que é a análise deste tipo de material e da prototipagem rápida (desconhecida por todos os entrevistados, sendo este mais um motivo para a apresentação da técnica).

\section{Coleta de dados relevantes:}

As características pessoais de cada indivíduo, discutidas acima, foram anotadas.

Início do tateamento das maquetes e primeiras impressões:

Depois das etapas acima, começa a avaliação propriamente dita. Nesta fase, existiram variações no início, uma vez que ocorreram reações diferenciadas no primeiro contato com a maquete em relação à sua disposição inicial. As maquetes foram dispostas da maneira como foram idealizadas (Fig. 5), com a legenda na parte superior, encaixada na maquete. 

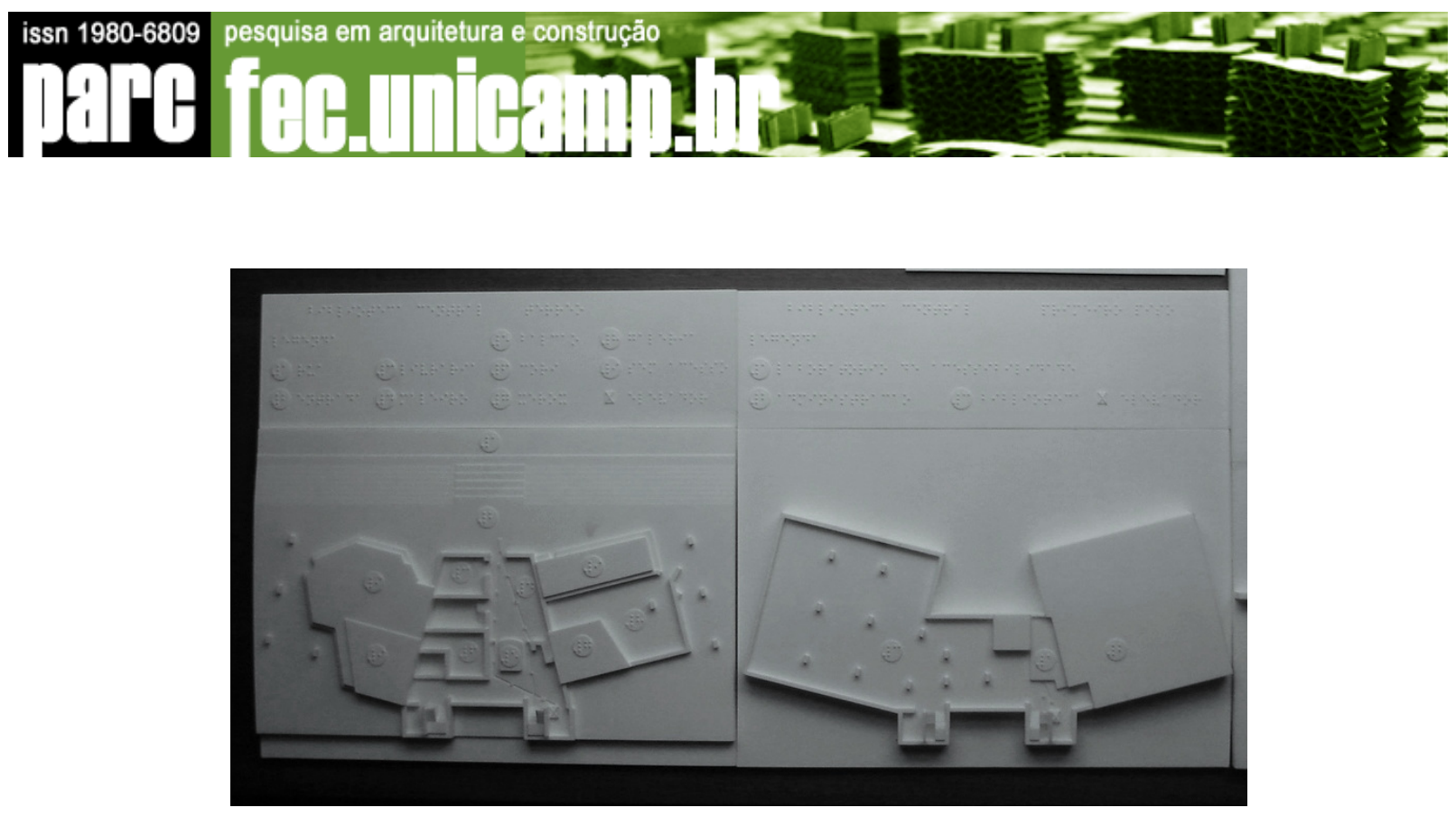

Fig.5 : Disposição idealizada das maquetes da biblioteca - início da avaliação

Desse modo, a entrada do térreo segue a seqüência da legenda, ou seja, segue a ordem de leitura do Braille (da esquerda para a direita, de cima para baixo) e a maquete do piso superior segue este posicionamento.

A segunda maquete, a do laboratório, foi apresentada como mostra a Fig. 6, com exceção da legenda que não possuía posição fixa.

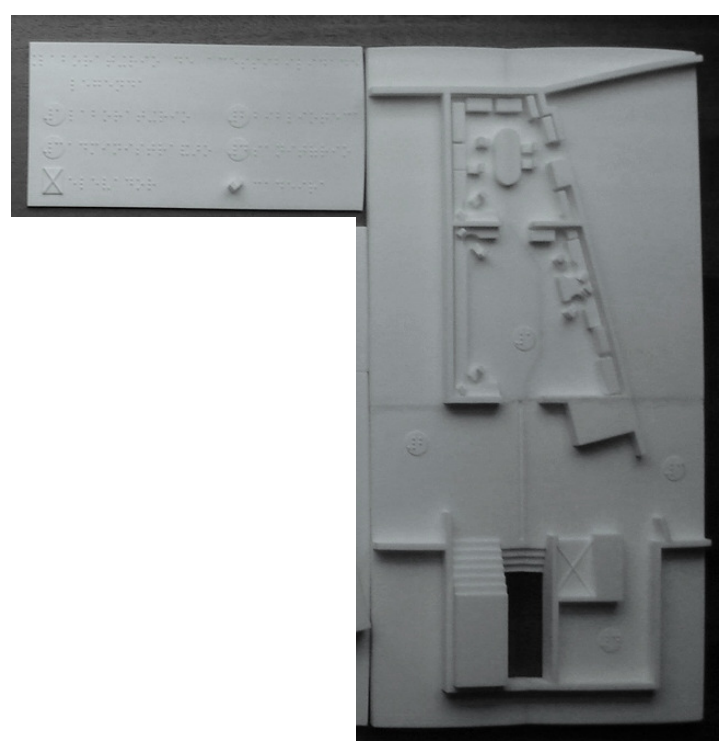

Fig. 6: Disposição idealizada das maquetes da biblioteca - início da avaliação.

Como foi dito anteriormente, houve certa divergência no primeiro contato com as maquetes, exclusivamente em relação à primeira entrevista, que compreendia na avaliação das 
maquetes da biblioteca. Três dos entrevistados começaram a leitura de baixo para cima, contrariando o esperado. De acordo com todos eles, esta reação é instintiva, quando se trata de visualização de maquetes, diferente do que ocorre na leitura do Braille. Isto, por sua vez, complicou a localização da legenda, fazendo com se demorasse mais para achá-la.

Dois dos participantes começaram a tatear a maquete aleatoriamente, não importando, em primeiro momento, a localização exata da legenda ou a disposição da maquete. Só depois de conseguir entender o contexto geral do modelo é que houve a preocupação com a discriminação de cada ambiente.

A maior diferença esteve na reação do indivíduo com baixa visão, que começou a leitura levando a maquete mais próxima da visão e tentando decifrar os pontos mais significativos. Só depois passou a tateá-la.

Diante das dificuldades apresentadas em achar uma referência que indicasse com clareza as disposições da maquete em relação ao trajeto que deve ser feito no interior da biblioteca, todos os participantes rotacionaram a maquete (Fig.7), tornando mais fácil o entendimento.

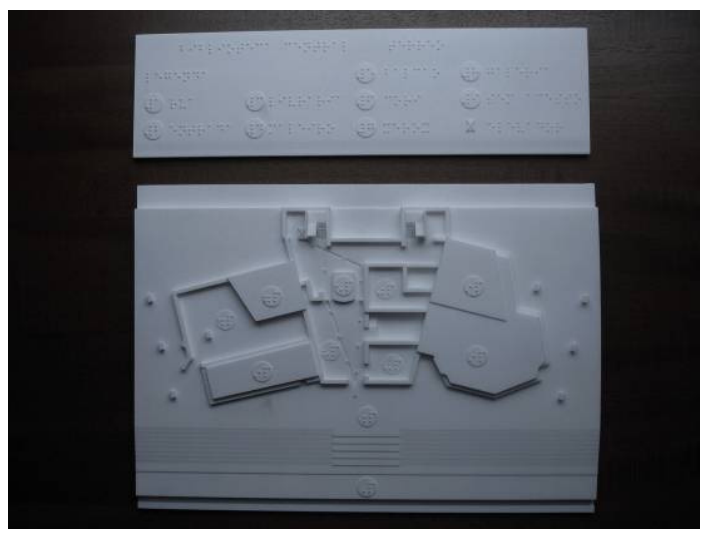

Fig. 7: Maquete rotacionada - a legenda fica solta e pode ser colocada onde for mais conveniente.

Desta maneira, a imagem da biblioteca se organizou, uma vez que tudo o que acontecia durante o trajeto na realidade acontecia no modelo. Ou seja, a entrada da biblioteca, após a rotação, está localizada a frente do indivíduo, permitindo que o trajeto até o laboratório seja feito como se estivesse caminhando pela maquete. $O$ ponto de referência, agora é a posição do indivíduo em relação ao edifício, dando maior coerência no entendimento dos ambientes.

No caso da segunda maquete, do laboratório, também foi difícil encontrar um ponto de referência, já que a escala se altera e, portanto, mudam-se as proporções. Isto implica em nova percepção do espaço. Além disso, o fato de ser um detalhe que não possui entrada e 
saída definidas (o início é a chegada pela escada) prejudica esta orientação. Talvez fosse mais interessante que se representasse apenas o próprio laboratório, começando diretamente com a representação da porta.

A localização da legenda é um item essencial, discutido em todas as entrevistas, visto que permite que a referência, que nos casos citados demorou a ser estabelecida, possa ser encontrada mais facilmente. Foram feitas diversas sugestões, como deixa-la solta para que seja adaptada conforme a necessidade ou que fosse colocada em toda a volta da maquete, mas a sugestão mais bem aceita foi de localizar a legenda na parte inferior do modelo, já que a maioria começou a ler a maquete por baixo.

A disposição da maquete do segundo pavimento também foi um fator bastante discutido, uma vez que é complicado fazer a conexão entre as duas maquetes. A escada muitas vezes não parecia explicativa, ou confundia em muitos momentos. Obviamente que alguns dos participantes não tiveram problemas, mas isto depende dos itens expostos anteriormente (tipo de deficiência etc). As sugestões para este problema indicaram duas possibilidades: a primeira, de se ter a primeira maquete rotacionada como descrito acima e a segunda disposta normalmente, caso as duas maquetes estejam juntas, por exemplo, colocadas no térreo da biblioteca (a disposição dos visitantes, deficientes visuais), mas que houvesse algum tipo de símbolo ou explicação que deixasse isso claro. Esta disposição deixaria os modelos "alinhados" ao movimento que o deficiente físico faz e percebe. A segunda hipótese é a de colocar cada maquete em seu piso correspondente e dispô-las de maneira que fique novamente alinhada com o trajeto do deficiente visual.

\section{Conclusões, apanhado geral dos pontos indicados durante a conversa}

A seqüência das entrevistas compreendia três itens que guiaram os comentários dos participantes. Estes itens são apresentados, descrevendo as conclusões tiradas da reunião de informações de todas as 6 entrevistas, relatando os pontos mais citados:

\section{Representação do espaço}

Este item tem como intenção avaliar as soluções encontradas para a representação dos elementos físicos da Biblioteca e do Laboratório. Os comentários aqui descritos, no entanto, são principalmente das maquetes da biblioteca central.

Escadas (Figs. 8 e 9) - houve sempre problemas no entendimento da escada, que não estava em escala adequada e, portanto, não permitia a percepção da sua forma 


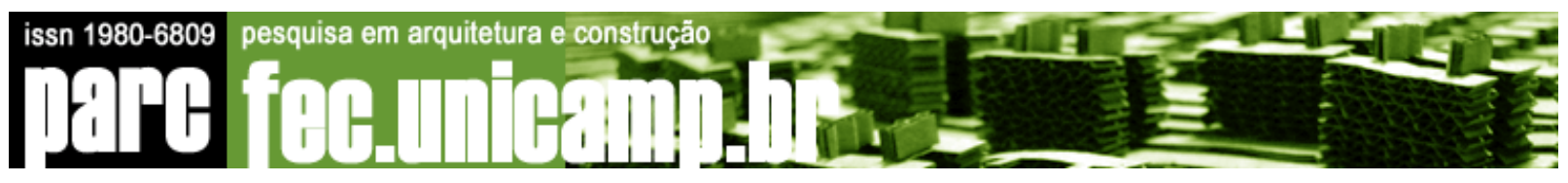

corretamente, por dois motivos: o primeiro, menos recorrente, é de o entrevistado não possuir imagem mental de como acontece espacialmente uma escada e não conseguir entendê-la pela maquete, sempre prejudicado pelo fato de não poder tocá-la corretamente. O segundo por não conseguir relacionar o caminho com a escada apresentada, de forma ideal, ou seja, o entrevistado conhece o funcionamento de uma escada, mas possui insegurança sobre este caso, recorrendo sempre a perguntas que confirmem sua percepção (na maioria dos casos, correta). Na maquete do laboratório de acessibilidade, ocorre o inverso, já que a escada é representada em escala maior, provocando confusão.
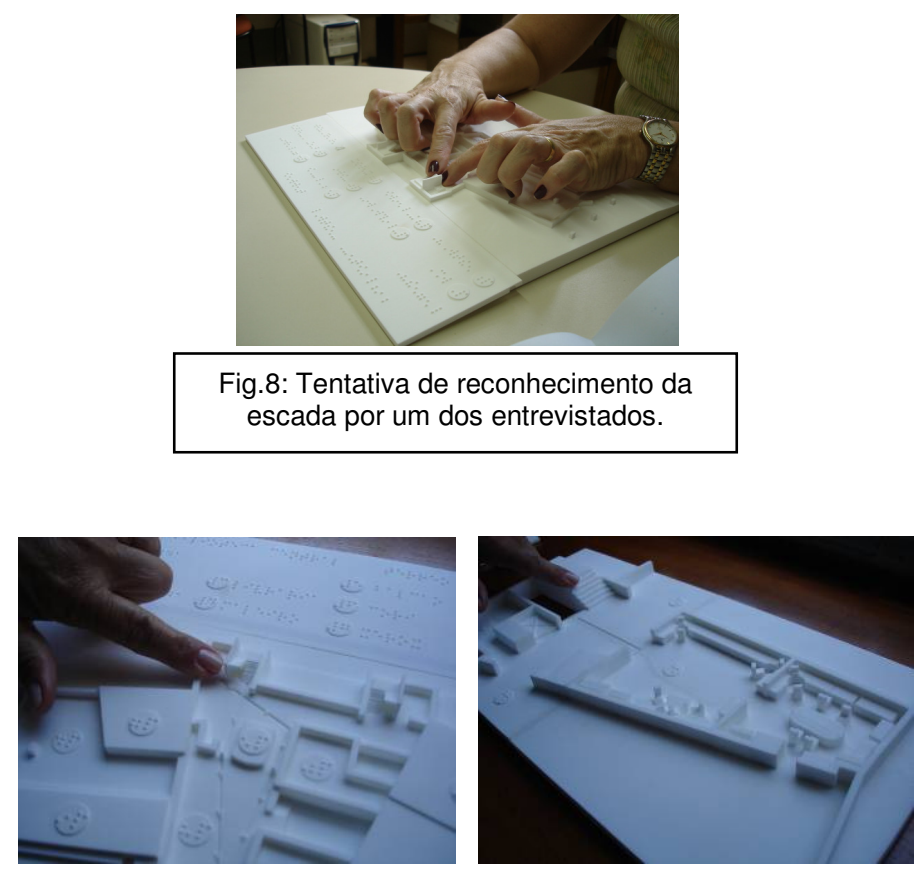

Fig.9: Diferenças de escala nas maquetes - confusão.

Relações com o entorno mais próximo/pontos de referência - a localização da biblioteca em relação ao seu entorno não dificultou a leitura da maquete, mas sempre foi lembrado que seria mais interessante se houvesse alguma indicação dos pontos de referência mais próximos (como o restaurante, o estacionamento), para que a percepção da maquete fosse melhorada.

Formas arquitetônicas - as formas dos ambientes, a relação entre suas dimensões, a sensação de perto e longe, a disposição de cada ambiente, os símbolos de parede e porta, as barreiras em geral, foram bem reconhecidos por todos os participantes. A única ressalva 


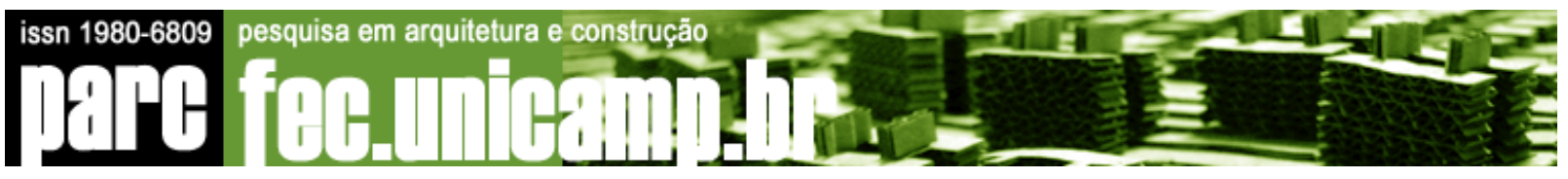

foi o fato de alguns elementos terem ficado um pouco pequenos (apesar de fáceis de ler) e que seria mais confortável se a escala da maquete fosse diminuída.

Vazios/espaços vazados/subsolo - não foi entendido de maneira correta por quase nenhum dos entrevistados (exceção do que já havia tido contato com o ambiente visualmente), talvez por causa da sua condição não tátil. No entanto, este item não tem profunda importância na leitura do restante da maquete o no entendimento do trajeto principal.

Representação de espaços não acessíveis - estes espaços são representados como sólidos, a fim de transmitir a sensação de ser espaços fechados, sem acesso. Contudo, os entrevistados preferem que estes espaços sejam representados como os locais acessíveis, por motivos de conhecimento total da biblioteca e que seja indicada a condição de espaço não acessível de outra maneira.

\section{Materiais}

Quanto ao material utilizado na produção das maquetes, houve a aceitação por todos os entrevistados. Os comentários foram positivos em relação à leveza, e a capacidade de oferecer boa representação do Braille, além da precisão na transmissão de informações, sem que existisse interferência na leitura.

A qualidade do material pôde ser comprovada devido a comparação com o pré-teste realizado na disciplina de Desenho Universal, citada no inicio deste relatório, no qual a maquete produzida era composta por materiais mais convencionais, como serragem, tecido, papel, o que causava certa confusão, uma vez que era inevitável a presença de imperfeições na junção destes materiais, o que atrapalha no tateamento. Neste caso, a prototipagem permite que não haja este tipo de problema.

A única sugestão foi que o modelo fosse mais liso, para que a textura que apresenta fosse aproveitada no detalhamento de alguns elementos de destaque (principalmente na maquete do laboratório, que exige maior detalhamento). Além disso, a textura diferenciada, que ocorre em eixos diferentes (na superfície, é mais liso que nas laterais), e que pode causar alguma dúvida, desapareceria.

\section{Elementos de legenda}

Este item é essencial para que haja boa representação das maquetes, já que deve guiar e transmitir as informações, esclarecendo os componentes da maquete. Por essa razão, sentiuse falta de algumas indicações, como sanitários (na primeira maquete), orelhão (bastante 


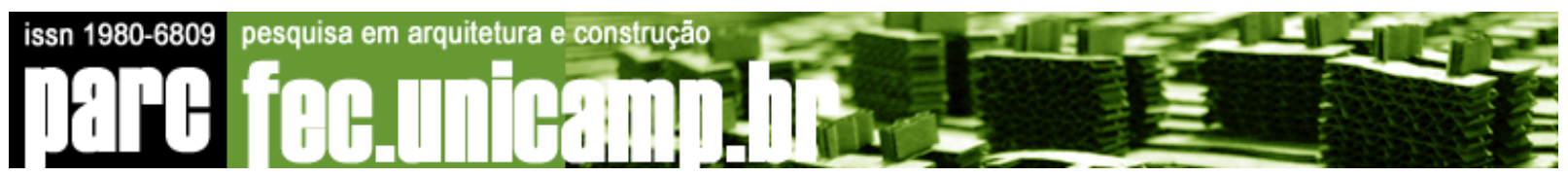

utilizado e sempre apontado como referência), catracas (na maquete ficaram pequenas demais e não possuíam identificação), pilares (no primeiro piso, na parte da biblioteca são os únicos elementos, já que as estantes não foram representadas - confusão).

Além disso, o símbolo utilizado para o elevador foi equivocado. Utilizou-se um X, como convencionado na representação em planta de arquitetura. Porém, essa indicação não é facilmente reconhecida. $O$ ideal, segundo todos os entrevistados é que se seguisse o padrão de legenda, indicando o elevador com um número.

Ao contrário, a representação da cadeira como um símbolo e não um número junto da legenda foi bem aceita, por causa da sua fácil correspondência com o objeto real.

Mas o mais interessante foi a sugestão de se indicar caminhos através dos números, estabelecendo duas funções diferentes para a legenda. A primeira é a comum, de nomear cada ambiente. A segunda de demarcar o trajeto principal através da ordem crescente de números, eliminando a necessidade de criar outras formas de indicação, o que poluiria a maquete e causaria confusão.

\section{Perguntas sobre imagem mental}

No final de cada entrevista, eram feitas algumas perguntas sobre a possível criação/ou mudanças de uma imagem mental da biblioteca em geral. Assim, as respostas seguiram certo padrão, mas os comentários mais específicos revelam diferenças nas percepções do edifício.

Por exemplo, um dos participantes, que já conheceu a biblioteca visualmente, diz que a maquete auxiliou no resgate desta memória, ajudando a reconstruir a imagem do edifício. Além disso, auxiliou na descoberta de mudanças não tão significativas ou drásticas, como aconteceu no hall de entrada, com a mudança das catracas e do balcão. Para o deficiente visual, tal deslocamento não é obvio, uma vez que ele não percebe imediatamente a disposição do entorno e utiliza sempre o mesmo trajeto. Com isso, consegue reformular a noção que possuía das características da biblioteca, confirmando, ainda, algumas dúvidas, com a da localização exata das duas escadas em relação à entrada.

Outro exemplo significativo foi a descoberta da relação que existe entre a galeria de arte e o xerox da biblioteca, que estão localizados na mesma ala e da posição da administração, logo ao lado do laboratório.

A percepção da forma principal do prédio também foi bastante comentada, já que é impossível adquirir uma noção do todo apenas com o contato direto. Esta noção geral 


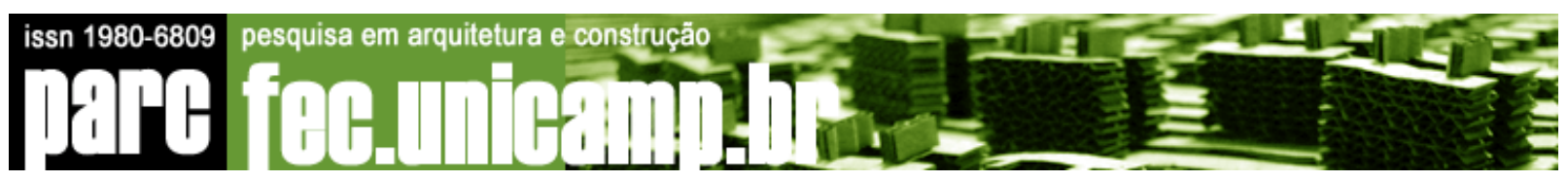

também revela a disposição das partes não acessíveis, como as laterais e a parte de trás da biblioteca.

Em relação ao laboratório, por ser um ambiente em que os participantes ficam e interagem, foi mais fácil perceber e reconhecer os detalhes. Mas o fato mais interessante foi a avaliação de um dos participantes que não utilizava o local com tanta freqüência e por isso não conhecia a disposição de objetos na sala. O participante lia na maquete os objetos e apontava-os no interior da sala, localizando-se de modo muito claro dentro do ambiente. A própria mesa em que maquete estava colocada estava representada. $\mathrm{O}$ indivíduo, quando analisou a mesa da maquete, por sua posição e dimensões, conferiu tateando a mesa e chegando a conclusão de que o modelo transmitia a noção correta.

Depois disso, ainda se movimentou no interior da sala, descrevendo novamente cada elemento e tentando recordar o que havia aprendido na maquete, com resultados satisfatórios.

\section{FOTOS DAS ENTREVISTAS}
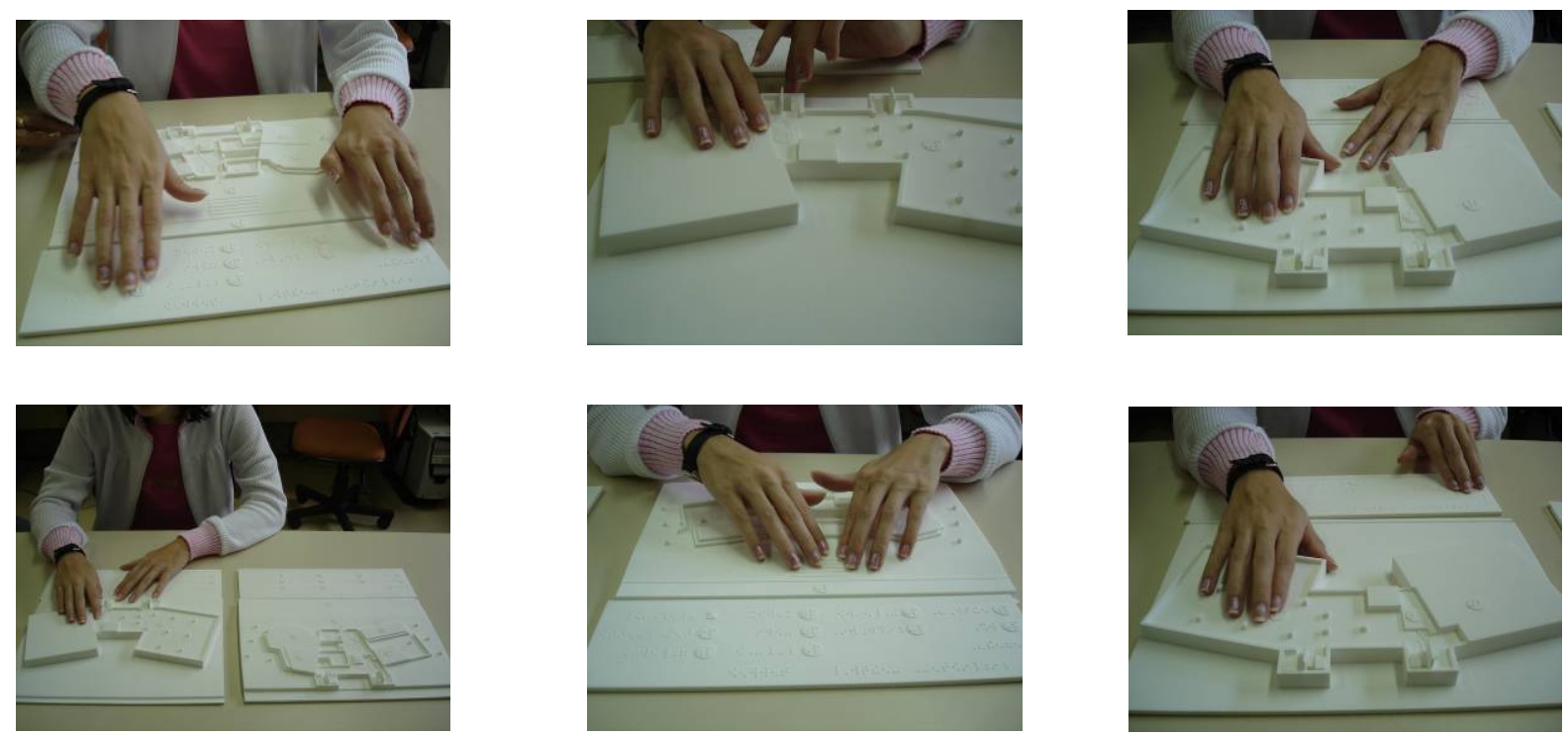

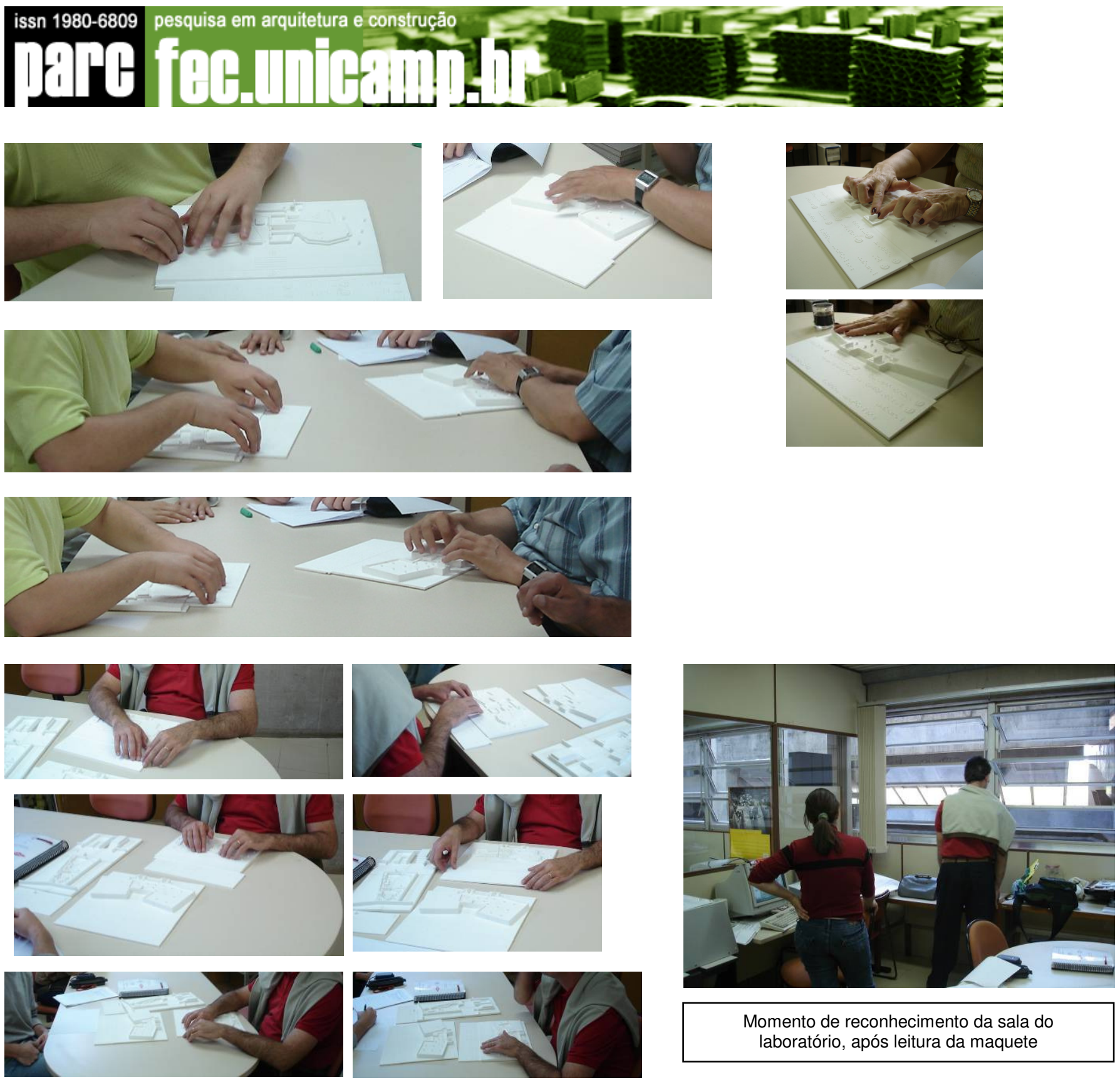

Momento de reconhecimento da sala do laboratório, após leitura da maquete

\section{Conclusão}

"A facilidade depende da pessoa. Eu tenho facilidade na orientação espacial."

"A baixa visão impede a construção do espaço de imediato e este tipo de recurso acelera 0 processo."

"É importante para quem tem baixa visão, porque dá noção anterior e gera menor insegurança ao caminhar."

"Antes a catraca era junto do maleiro, agora é na frente da entrada." 


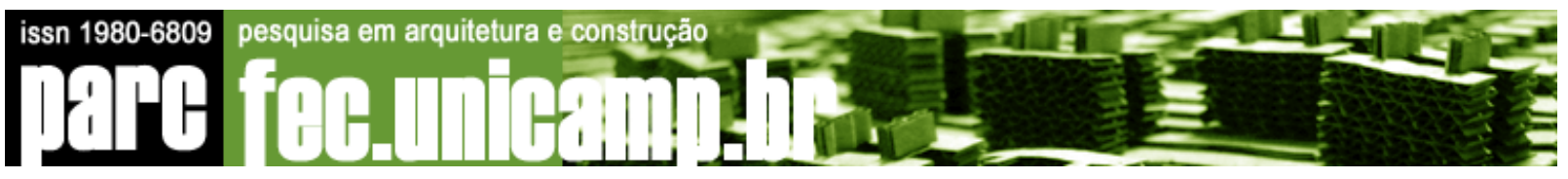

"Isso me ajuda a resgatar a imagem que tinha da biblioteca."

"O deficiente visual se orienta pelo tempo e é possível perceber as distâncias entre os ambientes."

"É interessante a visão do todo em miniatura."

"É mais eficiente que um mapa."

"O cego usa sempre referências."

"Eu que nunca entrei nesta biblioteca consegui perceber tudo. O caminho que eu fiz pra entrar está bem claro."

"Pra mim é mais prático pedir para alguém me levar até onde preciso ir."

"À primeira vista, o deficiente tem que estudar com calma."

Estas frases, ditas pelos participantes durante as entrevistas, mostram que a utilização de maquetes táteis na orientação espacial é eficiente e seria bem aceito se fossem disponibilizadas maquetes dos edifícios para que houvesse maior independência por parte dos portadores de deficiência visual. Mas todo o experimento mostra, também, que este tipo de recurso não é muito difundido, dificultando a sua implementação de maneira mais ampla, uma vez que não existe a prática para lidar com maquetes táteis. As duas últimas frases demonstram claramente o sentimento de insegurança de quem não possui esta experiência.

Em relação ao uso de prototipagem rápida, não houve nenhum problema, pelo contrário, foi muito bem aceito, devido à sua textura e capacidade de representação do Braille. O material utilizado se mostrou ideal por causa da durabilidade, resistência, leveza e facilidade de manuseio, correspondendo às necessidades deste tipo de maquete.

Assim sendo, pode-se dizer que a resposta à pergunta inicial desta pesquisa, se é possível realizar maquetes táteis usando prototipagem rápida, é afirmativa, dados os resultados apresentados. A maior dificuldade, contudo, consiste no projeto adequado de uma maquete tátil, já que os aspectos negativos dos modelos mostrados aqui se referem à problemas de escala e simbologias adotadas.

\section{Agradecimentos}

O autor gostaria de agradecer às seguintes pessoas e entidades pela sua colaboração nesta pesquisa:

- À Profa. Gabriela Celani, da Faculdade de Engenharia Civil, Arquitetura e Urbanismo da UNICAMP, pela orientação desta pesquisa de Iniciação Científica. 


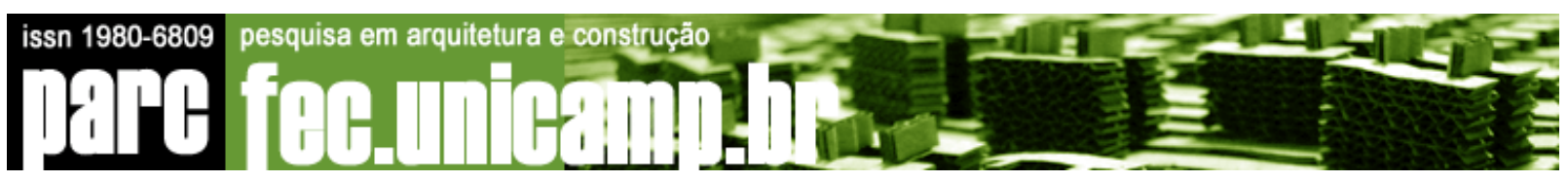

- Ao CNPq pela concessão da bolsa de Iniciação Científica, que tornou possível esta pesquisa.

- Ao Laboratório de prototipagem rápida do Centro de Pesquisas Renato Archer, e em especial a Jorge Lopez e Carlos Saura, pela produção das maquetes em SLS.

- Ao Laboratório de Acessibilidade da Biblioteca Central da UNICAMP, pela atenção e recrutamento de usuários para avaliação das maquetes produzidas.

- A todos os usuários do Laboratório de Acessibilidade que participaram da avaliação das maquetes produzidas.

- Às Profas. Doris Kowaltowski e Núbia Bernardi, por suas valiosas sugestões e esclarecimentos durante a pesquisa.

\section{Referências}

Jehoel, S., et. al., "An Evaluation of Substrates for Tactile Maps and Diagrams: Scanning Speed and Users' Preferences”. Journal of Visual Impairment \& Blindness v. 99 no. 2, p.8595, 2005

Holmes, E., et. al., "Wall versus path tactile maps for route planning in buildings". Journal of Visual Impairment \& Blindness v. 92 no. 7, p.531-4, 1998.

Ungar, S., Espinosa, A., BLADES, M., Ochaíta, E. \& SPENCER, C. "Blind and visually impaired people using tactile maps". Proceedings of the Association 11 of American Geographers Annual Meeting, Charlotte, North Carolina: Association of American Geographers, p.1-5, 1996 (disponível em http:/www.surrey.ac.uk/ pss1su/research/ papers/cartpers.rtf).

Ungar, S., BLADES, M. \& SPENCER, C. "Visually impaired children's strategies for memorizing a map". British Journal of Visual Impairment, 13, p.27-32, 1995.

SEESP - Secretaria de Educação Especial, Ministério da Educação. Documento Orientador. 2006 (disponível em http://portal.mec.gov.br/seesp/arquivos/pdf/ orientador2006.pdf). 


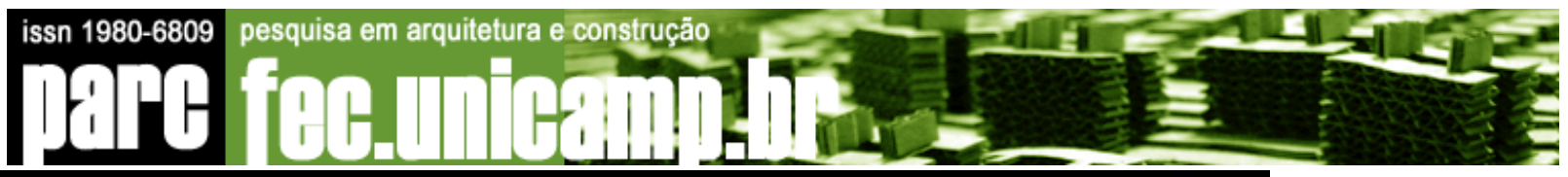

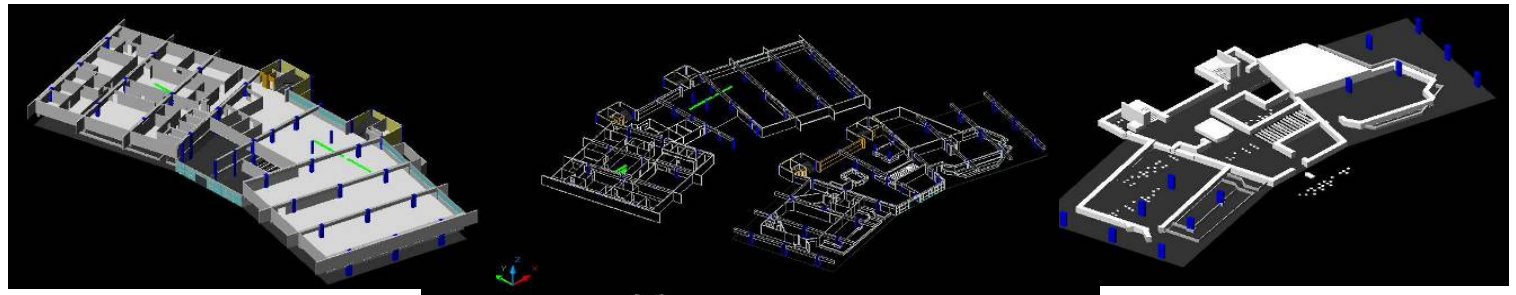

ANEXO A

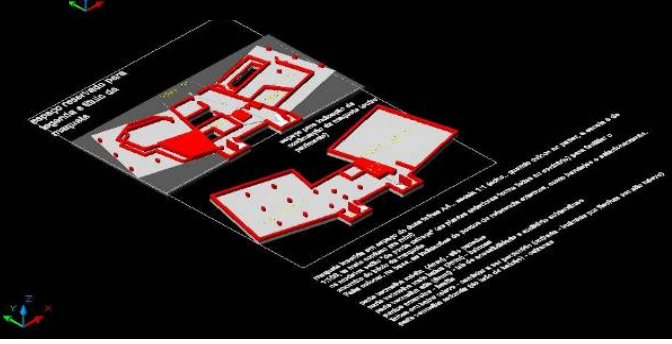

Alguns estudos de volumetria para a produção da maquete tátil da biblioteca - do modelo comum ao tátil.
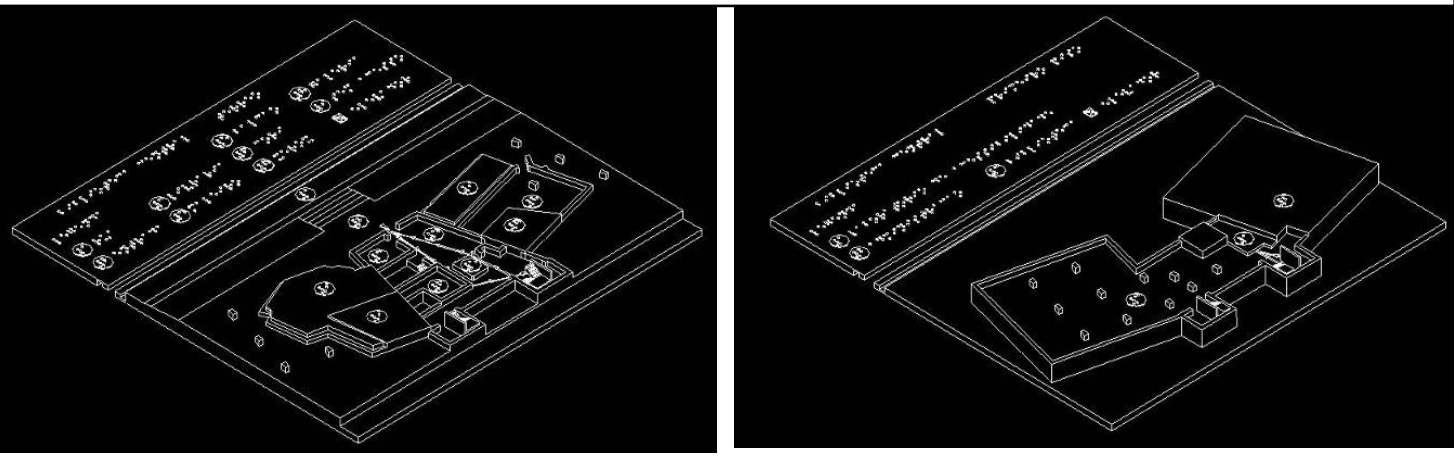

Modelos utilizados para a produção das maquetes em Prototipagem Rápida

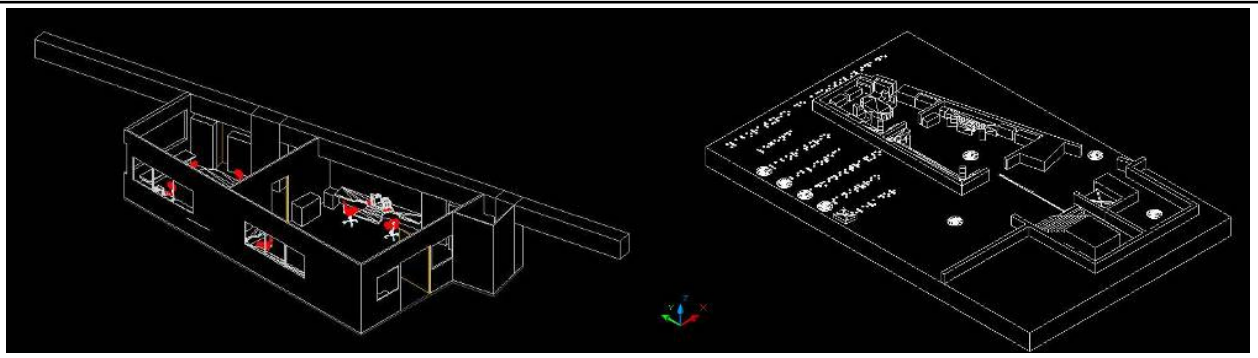

Alguns estudos de volumetria para a produção da maquete tátil do laboratório - do modelo comum ao tátil.

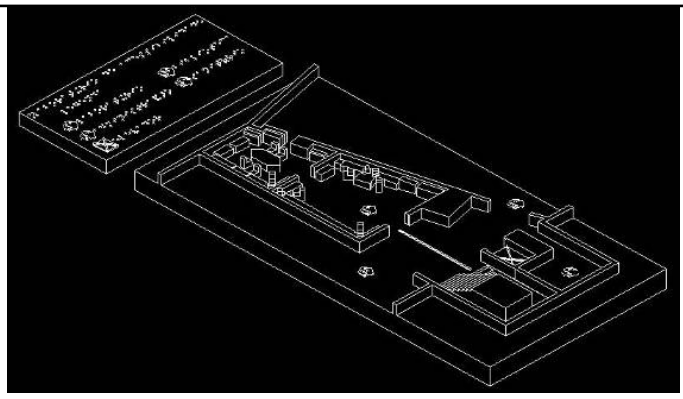

Modelo utilizado para a produção da maquete em Prototipaqem Rápida 